\title{
LIMING EFFECTS ON GROWTH OF NATIVE WOODY SPECIES FROM BRAZILIAN SAVANNAH ${ }^{1}$
}

\author{
ANTONIO EDUARDO FURTINI NETO², ÁLVARO VILELADE RESENDE³, \\ FABIANO RIBEIRO DO VALE ${ }^{4}$ and IVO RIBEIRO SILVA ${ }^{3}$
}

\begin{abstract}
The liming effects on the growth of fifteen woody species of Brazil were evaluated under glasshouse conditions. The species used belong to different ecologic groups, namely: pioneer, secondary and climax trees. The soil treatments consisted in the absence of liming (-LIM) and liming sufficient to reach soil pH 6.0 (+LIM). In general, the pioneer and secondary species presented higher responses in total dry matter production (TDM) to soil liming, whereas the TDM of the climax species were not affected by the soil treatments. Thus, the ranking of species in relation to soil acidity tolerance ranged from highly sensitive to highly tolerant. The pioneer and secondary species growing in limed soil $(+\mathrm{LIM})$ showed higher calcium $(\mathrm{Ca})$, magnesium $(\mathrm{Mg})$ and phosphorus $(\mathrm{P})$ contents, and, at the same time lower $\mathrm{Ca}, \mathrm{Mg}$ utilization efficiency ( $\mathrm{CaUE}$ and $\mathrm{MgUE}$ respectively), whereas the $\mathrm{P}$ utilization (PUE) was higher. In contrast, the $\mathrm{Ca}, \mathrm{Mg}$ and $\mathrm{P}$ content in the climax species were only slightly affected by the soil liming. In general the climax species were less efficient in the $\mathrm{CaUE}$ and MgUE than the pioneer and secondary species.
\end{abstract}

Index terms: acid soil, ecological groups, nutrient utilization efficiency.

\author{
EFEITOS DA CALAGEM NO CRESCIMENTO DE ESPÉCIES FLORESTAIS \\ DA REGIÃO DOS CERRADOS BRASILEIROS
}

\begin{abstract}
RESUMO - Em condições de casa de vegetação foram avaliados os efeitos da calagem no crescimento de quinze espécies florestais nativas do Brasil. Foram utilizadas espécies pertencentes aos grupos ecológicos de plantas pioneiras, secundárias e clímax. Os tratamentos de solo consistiram na ausência de calagem (-LIM) e calagem até atingir $\mathrm{pH}=6,0$ ( $+\mathrm{LIM})$. Em geral, as espécies pioneiras e secundárias apresentaram as maiores respostas à calagem quanto à produção de matéria seca total (TDM), enquanto que as espécies clímax não foram afetadas pelos tratamentos de solo. A classificação das quinze espécies em relação à tolerância à acidez do solo variou de altamente sensíveis a altamente tolerantes. As espécies pioneiras e secundárias, quando cresceram em solo corrigido (+LIM), apresentaram maiores conteúdos de $\mathrm{Ca}, \mathrm{Mg}$ e $\mathrm{P}$ e baixa eficiência de utilização de Ca e $\mathrm{Mg}$ (CaUE e MgUE, respectivamente); porém, a eficiência de utilização de $\mathrm{P}$ (PUE) foi maior neste tratamento. Em contraste, os conteúdos de Ca, $\mathrm{Mg}$ e P das espécies clímax foram apenas levemente afetados pela calagem. Em geral, as espécies clímax foram menos eficientes do que as pioneiras e secundárias em utilizar o $\mathrm{Ca}$ e o $\mathrm{Mg}$.
\end{abstract}

Termos para indexação: solo ácido, grupos ecológicos, eficiência de utilização de nutrientes.

\footnotetext{
${ }^{1}$ Accepted for publication on May 5, 1998.

Partially funded by CEMIG and FAPEMIG.

2 Agronomist, Dr., Dep. de Ciência do Solo, Universidade Federal de Lavras (DCS/UFLA), CEP 37200-000 Lavras, MG. CNPq. scholar. E-mail:afurtini@ufla.br

${ }^{3}$ Agronomist, Graduate Student, DCS/UFLA.

${ }^{4}$ Agronomist, Ph.D., Titular Professor, DCS/UFLA.
}

\section{INTRODUCTION}

In Brazil, in the last decades, the native forest species have been subjected to a continuous and disorganized process of exploitation, which is causing a great reduction of the area formerly occupied by them. These native forest areas are very important 
because they are not only the site of plant but also of animal biodiversity. Thus, in the last years, there have been an increasingly interest in planting woody species, not only with economic purpose but also with environmental emphasis. However, one of the most frequently found problem has been the lack of studies on nutritional requirements of these species as well as their sensitivity to different chemical and physical soil constraints (Siqueira et al., 1995). Since most Brazilian soils, mainly those in the Cerrado region, which comprise around 200 millions ha, have high acidity, low natural fertility and high $\mathrm{Al}$ saturation (Lopes, 1983), the chemical limitation to plant growth can be severe. So, after a basal fertilization, the present paper evaluates the effects of soil liming on the initial growth of fifteen woody species from Brazil.

\section{MATERIALAND METHODS}

The experiment was carried out under glasshouse conditions, with natural light, at the Universidade Federal de Lavras, Brazil. The soil utilized in the study is an allic, medium textured Cambisol (Inceptisol), collected from the forest-cerrado transition in Itumirim, at the Minas Gerais State, Brazil.

After being air dried and passed through a $5 \mathrm{~mm}$ sieve, the soil was limed using $\mathrm{CaCO}_{3}$ and $\mathrm{MgCO}_{3}(4: 1 \mathrm{w} / \mathrm{w})$. Liming was applied in a quantity enough to raise the soil $\mathrm{pH}$ to $6.0\left(3.6 \mathrm{Mg}\right.$. $\mathrm{ha}^{-1}$, as previously determined by titration curves). Then, the soil was placed in $5 \mathrm{dm}^{3}$ pots $(3.7 \mathrm{~kg})$, and maintained wet during 15 days. The soil treatments consisted of the absence (-LIM) and presence $(+\mathrm{LIM})$ of lime. Soils of both treatments received a basal fertilizer application of $50 \mathrm{mg} \mathrm{kg}^{-1} \mathrm{~N}, 70 \mathrm{mg} \mathrm{kg}^{-1} \mathrm{~K}$, $100 \mathrm{mg} \mathrm{kg}^{-1} \mathrm{P}, 30 \mathrm{mg} \mathrm{kg}^{-1} \mathrm{~S}, 4 \mathrm{mg} \mathrm{kg}{ }^{-1} \mathrm{Zn}, 1 \mathrm{mg} \mathrm{kg}^{-1} \mathrm{~B}$ and $1 \mathrm{mg} \mathrm{kg}^{-1} \mathrm{Cu}$. The liming and fertilization treatments produced an increase in soil $\mathrm{pH}$ and concentrations of $\mathrm{Ca}^{2+}$ and $\mathrm{Mg}^{2+}$, lowering the $\mathrm{Al}^{3+}$ (Table 1). A total of 15 woody species were used in the study (Table 2). Six seeds of each species were planted directly in the pots, and 10 days after emerging they were thinned to 2 seedlings per pot. Pots were assigned to a completely randomized design, in a full factorial combination of absence (-LIM) and presence (+LIM) of lime and 15 tree species, with 6 replicates each. During the whole experiment, pots were watered daily with demineralized water, to $90 \%$ of field capacity $(30 \% \mathrm{w} / \mathrm{w}$ at $3.3 \mathrm{kPa})$. At 60,90 and 120 days after sowing, each pot of both treatments received a tipdressing of $50 \mathrm{mg} \mathrm{N} \mathrm{kg}^{-1}$ of soil, as $\mathrm{NH}_{4} \mathrm{NO}_{3}$.

Before cutting the plants (150 days after emerging), the plant stem diameter (SD) as well as the plant height (PLH) were measured. The plant material was separated into shoot and roots. Roots were washed free of soil through a $2 \mathrm{~mm}$ sieve using tap water. Washed roots and shoots were oven dried at about $65^{\circ} \mathrm{C}$ until constant weight. Dried material was weighed for determining yielding the shoot dry matter (SDM), root dry matter (RDM), and total dry matter (TDM). The dried material was ground and digested in concentrated nitric acid $(20 \mathrm{mhL})$ and $100 \%$ perchloric acid ( $2 \mathrm{mhL}$ ). Digests were analyzed for $\mathrm{Ca}$ and $\mathrm{Mg}$ using atomic absorption spectrophotometry and for $\mathrm{P}$ using colorimetry. The total nutrient content (TNC) was calculated as the product of nutrient concentration and dry matter. The nutrient utilization efficiency was calculated for $\mathrm{Ca}, \mathrm{Mg}$ and $\mathrm{P}$, hereafter named $\mathrm{CaUE}, \mathrm{MgUE}$ and PUE, respectively, as the ratio (TDM) ${ }^{2}(\mathrm{TNC})^{-1}$ (Siddiqi \& Glass, 1981). Soil extractable $\mathrm{Ca}, \mathrm{Mg}$ and $\mathrm{Al}$ were extracted with $1 \mathrm{mmol} \mathrm{hL}^{-1} \mathrm{KCl}$. Ca and $\mathrm{Mg}$ were determined by atomic absorption spectrophotometry and $\mathrm{Al}$ by titration. Soil $\mathrm{P}$ and $\mathrm{K}$ were extracted with a Mehlich 1 solution and determined by colorimetry and flame fotometry, respectively.

All the species were ranked for soil acidity tolerance using an index slightly modified from Ashwath et al. (1995), calculated in the following way: (TDM (unlimed soil) x (TDM (limed soil) $)^{-1} \times 100$. The ranking was organized by placing the species into the following five groups, according to the established indices: highly tolerant $(>120 \%)$, tolerant $(90-120 \%)$, moderately tolerant $(70-90 \%)$, sensitive (50-70\%), and highly sensitive $(<50 \%)$.

TABLE 1. Selected soil chemical characteristics after liming and basal fertilization.

\begin{tabular}{|c|c|c|c|c|c|c|}
\hline \multirow[t]{2}{*}{ Soil treatments } & \multirow{2}{*}{$\begin{array}{c}\mathrm{pH} \\
\left(\mathrm{H}_{2} \mathrm{O}\right)\end{array}$} & \multirow[t]{2}{*}{$\mathrm{P}$} & \multicolumn{4}{|c|}{ Exchangeable cations } \\
\hline & & & $\mathrm{K}^{+}$ & $\mathrm{Ca}^{2+}$ & $\mathrm{Mg}^{2+}$ & $\mathrm{Al}^{3+}$ \\
\hline & & $\left(\mathrm{mg} \mathrm{dm}^{-3}\right)$ & --------- & $---(m$ & $\left.\mathrm{n}^{-3}\right)$ & $-\cdots$ \\
\hline Without liming (-LIM) & 4.5 & 38.0 & 2.7 & 4.0 & 1.5 & 6.0 \\
\hline With liming & 6.1 & 38.0 & 2.6 & 27.0 & 5.0 & 1.0 \\
\hline
\end{tabular}


TABLE 2. Characterization of the studied woody species by ecologic groups.

\begin{tabular}{lll}
\hline Species & Family & Ecologic group $^{1}$ \\
\hline Hovenia dulcis Thumb. & Rhamnaceae & Pioneer \\
Trema micrantha Bloom & Ulmaceae & Pioneer \\
Peltophorum dubium (Spreng) Taub. & Caesalpinaceae & Pioneer \\
Schinus terebinthifolius Raddi. & Anacardiaceae & Pioneer \\
Stenolobium stans (Jun.) Seem. & Bignoniaceae & Pioneer \\
Anadenanthera falcata (Benth.) Speg. & Mimosaceae & Pioneer \\
Jacaranda mimosifolia D. Don. & Bignoniaceae & Pioneer \\
Senna multijuga (L.C. Rich) I.\&B. & Caesalpinaceae & Pioneer \\
Cedrella fissilis Vell. & Meliaceae & Secondary \\
Luehea grandiflora Marth et Zucc. & Tiliaceae & Secondary \\
Senna macranthera (Collad.) I.\&B. & Caesalpinaceae & Secondary \\
Aspidosperma parvifolium A. DC. & Apocynaceae & Climax \\
Platycyamus regnellii Benth. & Papilionaceae & Climax \\
Hymenaea courbaril L. & Caesalpinaceae & Climax \\
Copaifera langsdorffii Desf. & Caesalpinaceae & Climax \\
\hline
\end{tabular}

${ }^{1}$ According to Budowsky (1965)

The data were submitted to analysis of variance and to the Tukey's test at 0.05 , using the statistical package SAEG (Universidade Federal de Viçosa)

\section{RESULTS AND DISCUSSION}

The liming effects on plant growth were markedly different, varying in function of the species and their ecological group. In general, higher responses were observed for the pioneer and secondary species, whereas the climax ones were practically responsiveless to soil liming (Table 3). Except for Hovenia dulcis, Anadenanthera falcata and Jacaranda mimosifolia (pioneer species), liming promoted the plant stem diameter (SD) growth of all species. However, only three pioneer species (Trema micrantha, Schinus terebinthifolius and Senna multijuga) and two secondary ones (Cedrella fissilis, Luehea grandiflora) showed response in plant height (PLH). In the climax species, neither the SD nor the PLH were changed with soil liming. Since the species have different growth patterns, it appeared that the SD was a better parameter than PLH to evaluate plant growth.

When the plants were growing in the limed soil, all the pioneer and secondary species, except H. dulcis and A. falcata, which had a reduced shoot growth with soil liming, showed a significantly increase in the shoot dry matter (SDM). On the other hand, the climax species had similar SDM in the -LIM and +LIM soil treatments. The root growth of the pioneer species such as S. terebinthifolius and Stenolobium stans was impaired by the soil acidity, whereas the root dry matter (RDM) of the A. falcata was bigger in the unlimed soil. The climax species Platycyamus regnelli also had a smaller RDM in the amended soil (+LIM) (Table 3).

Although considered as an essential element to plant growth when in low concentrations (Huang $\&$ Bachelard, 1993), Al becomes a toxic metal in higher concentrations, decreasing plant yield, mainly by the reduction of the roots (Foy, 1988; Delhaize \& Ryan, 1995). In acid soils, Ca defficiency must be considered as a limiting factor to the root growth (Smyth \& Cravo, 1992; Vale et al., 1996), and in some situations it can even turn into a more limiting factor than the Al toxicity (Ritchey et al., 1982). In addition to that, low Mg levels (Tan \& Keltjens, 1995), and even the $\mathrm{H}^{+}$excess (Blamey et al., 1987; Sanzonowicz \& Smyth, 1995) may, directly or indiretly, reduce the dry matter production. The soil liming in the present experiment increased concentrations of $\mathrm{Ca}$ and $\mathrm{Mg}$ and decreased considerably the $\mathrm{Al}$ concentration (Table 1). Nonetheless, when lime was omitted, only the RDM of the S. terebinthifolius and S. stans decreased, and for species such as A. falcata and 
TABLE 3. Plant height (PLH), stem diameter (SD), root (RDM), shoot (SDM) and total dry matter (TDM), in the unlimed (-lim) and limed (+lim) acid soil. Values are means of six replicates.

\begin{tabular}{|c|c|c|c|c|c|c|c|c|c|c|}
\hline \multirow[t]{2}{*}{ Species } & \multicolumn{2}{|c|}{ PLH } & \multicolumn{2}{|c|}{ SD } & \multicolumn{2}{|c|}{ RDM } & \multicolumn{2}{|c|}{ SDM } & \multicolumn{2}{|c|}{ TDM } \\
\hline & $-\lim$ & $+\lim$ & $-\lim$ & $+\lim$ & $-\lim$ & $+\lim$ & $-\lim$ & $+\lim$ & $-\lim$ & $+\lim$ \\
\hline & \multicolumn{2}{|c|}{------(cm)----- } & \multicolumn{2}{|c|}{-----(mm)----- } & \multicolumn{6}{|c|}{ - } \\
\hline Hovenia dulcis & 34.7 & 32.7 & 34.5 & 38.3 & 2.30 & 2.15 & 4.25 & 3.77 & 6.55 & 5.91 \\
\hline Trema micrantha & 10.6 & 20.8 & 16.0 & 27.5 & 0.10 & 0.31 & 0.63 & 2.82 & 0.73 & 3.13 \\
\hline Peltophorum dubium & 32.1 & 37.3 & 72.2 & 79.3 & 6.33 & 6.93 & 15.80 & 20.4 & 22.1 & 27.3 \\
\hline Schinus terebinthifolius & 32.1 & 51.9 & 31.8 & 54.0 & 2.14 & 3.73 & 5.33 & 13.7 & 7.48 & 17.4 \\
\hline Stenolobium stans & 42.0 & 47.5 & 47.8 & 55.7 & 4.53 & 7.85 & 9.66 & 14.8 & 14.2 & 22.7 \\
\hline Anadenanthera falcata & 35.8 & 36.3 & 33.5 & 32.7 & 2.58 & 1.25 & 7.34 & 6.60 & 9.92 & 7.85 \\
\hline Jacaranda mimosifolia & 27.8 & 33.2 & 45.0 & 48.3 & 2.90 & 2.49 & 9.50 & 12.9 & 12.4 & 15.3 \\
\hline Senna multijuga & 44.5 & 66.9 & 45.8 & 54.0 & 4.88 & 4.49 & 11.9 & 19.4 & 16.8 & 23.9 \\
\hline Mean for pioneer species & 32.5 & 40.8 & 40.8 & 48.7 & 3.20 & 3.70 & 8.10 & 11.8 & 11.3 & 15.4 \\
\hline Cedrella fissilis & 15.4 & 30.2 & 51.3 & 93.5 & 0.78 & 3.60 & 4.58 & 11.4 & 5.36 & 15.0 \\
\hline Luehea grandiflora & 43.6 & 58.7 & 65.0 & 79.7 & 0.96 & 2.29 & 6.48 & 11.3 & 7.44 & 13.6 \\
\hline Senna macranthera & 29.3 & 31.6 & 54.3 & 57.8 & 4.74 & 4.83 & 11.8 & 15.6 & 16.6 & 20.4 \\
\hline Mean for secondary species & 29.4 & 40.2 & 56.9 & 77.0 & 2.20 & 3.60 & 7.60 & 12.8 & 9.80 & 16.3 \\
\hline Aspidosperma parvifolium & 19.0 & 28.1 & 44.5 & 39.0 & 1.85 & 1.05 & 3.93 & 2.32 & 5.78 & 3.37 \\
\hline Platycyamus regnellii & 22.4 & 22.3 & 49.2 & 44.8 & 3.76 & 2.20 & 7.61 & 6.90 & 11.4 & 9.10 \\
\hline Hymenaea courbaril & 35.0 & 32.3 & 44.8 & 45.3 & 2.63 & 2.44 & 6.84 & 6.52 & 9.47 & 8.96 \\
\hline Copaifera langsdorffii & 13.7 & 14.0 & 28.0 & 27.2 & 1.30 & 1.27 & 1.96 & 2.04 & 3.26 & 3.31 \\
\hline Mean for climax species & 22.5 & 24.2 & 41.6 & 39.1 & 2.40 & 1.70 & 5.10 & 4.45 & 7.50 & 6.20 \\
\hline Variation coefficient (\%) & \multicolumn{2}{|c|}{20.6} & \multicolumn{2}{|c|}{12.8} & \multicolumn{2}{|c|}{29.5} & \multicolumn{2}{|c|}{21.5} & \multicolumn{2}{|c|}{21.4} \\
\hline LSD soil liming (5\%) & \multicolumn{2}{|c|}{7.62} & \multicolumn{2}{|c|}{6.96} & \multicolumn{2}{|c|}{0.98} & \multicolumn{2}{|c|}{2.09} & \multicolumn{2}{|c|}{2.79} \\
\hline LSD species $(5 \%)$ & \multicolumn{2}{|c|}{13.2} & \multicolumn{2}{|c|}{12.1} & \multicolumn{2}{|c|}{1.7} & \multicolumn{2}{|c|}{3.6} & \multicolumn{2}{|c|}{4.8} \\
\hline
\end{tabular}

P. regnelli the soil liming was harmful (Table 3 ). That ilustrates the distinct responses of different plant species. Vale et al. (1996) also found a great diversity in the performance of various forest species when planted in an acid soil. In their study, Eucalyptus grandis, Acacia mangium and Pelthophorum dubium showed the RDM not affected in the unlimed soil, whereas Enterolobium contortisiliquum, Melia azedarach and Leucaena sp. were highly sensitive to the acid soil conditions, increasing the RDM production with soil liming.

In the present study, in contrast with most of the pioneer and secondary species, the total dry matter (TDM) (and also the SD, PLH and SDM) of the climax ones, was not affected by liming (Table 3 ).
It is important to emphasize the differential response of the species concerning the soil acidity, not only among ecologic groups, but also among species belonging to the same group. In the set of the pioneer species used, for instance, $S$. terebinthifolius showed the highest response to the soil liming, with great increments both in SDM and RDM, reaching gains of $150 \%$ in the TDM. Nevertheless, in the unlimed soil, H. dulcis and $A$. falcata were able to yield 20 and $25 \%$ more TDM than in the amended soil, respectively (Table 3 ). Elsewhere, high responses to lime application have been obtained for Astronium urundeuva (Costa Filho, 1992), while Acacia species behaved in a distinct manner when planted in acid soil of Australia 
(Ashwath et al., 1995), ranging from sensitive to highly tolerant. Differences in the tolerance to soil acidity was observed by Huang \& Bachelard (1993), who found that while Eucalyptus mannifera grew very well, Pinus radiata failed to do it.

The soil liming effects were reflected in the plant total nutrient content (TNC) of the pioneer and secondary species, which demonstrated higher $\mathrm{Ca}$ and $\mathrm{Mg}$ content with soil liming (Table 4), whereas the $\mathrm{P}$ content was bigger only in three pioneer species (H. dulcis, A.falcata and J. mimosifolia). In the climax species, only the $P$. regnellii plants had higher $\mathrm{Ca}$ and $\mathrm{Mg}$ contents with liming (Table 4 ). On the other hand, their $\mathrm{P}$ contents were similar to the other climax species, in both limed and unlimed soil.
The bigger total content of $\mathrm{Ca}, \mathrm{Mg}$ and $\mathrm{P}$ in the pioneer and secondary species in relation to climax ones suggest higher requirements for these nutrients and, therefore, bigger increases in the TDM when lime was applied. That agrees with results of Nielsen et al. (1990) who found that plants of Prunus avium L. presented higher acquisition of nutrients when growing in limed soil. However, in the present study, the increases in the TNC, mainly because of the $\mathrm{Ca}$ and $\mathrm{Mg}$ added via soil liming (Table 4), were not always followed by proportional responses in the TDM (Table 3). In general, the species, independently of their ecological group, revealed to be more efficient in the $\mathrm{Ca}$ and $\mathrm{Mg}$ utilization in the -LIM treatment than in the +LIM one, and the CaUE and MgUE

TABLE 4. Total nutrient content of the forest species under limed (+lim) and unlimed (+lim) treatments. Values are means of six replicates.

\begin{tabular}{|c|c|c|c|c|c|c|}
\hline \multirow[t]{3}{*}{ Species } & \multicolumn{6}{|c|}{ Total nutrient content } \\
\hline & \multicolumn{2}{|c|}{$\mathrm{Ca}$} & \multicolumn{2}{|c|}{$\mathrm{Mg}$} & \multicolumn{2}{|c|}{$\mathrm{P}$} \\
\hline & $-\lim$ & $+\lim$ & $-\lim$ & $+\lim$ & $-\lim$ & $+\lim$ \\
\hline & \multicolumn{6}{|c|}{ - } \\
\hline Hovenia dulcis & 47.0 & 82.4 & 8.82 & 26.0 & 7.6 & 9.1 \\
\hline Trema micrantha & 13.4 & 117 & 1.94 & 16.7 & 1.8 & 9.2 \\
\hline Peltophonim dubium & 87.1 & 249 & 13.9 & 42.2 & 26.6 & 34.6 \\
\hline Schinus terebinthifolius & 53.3 & 203 & 6.28 & 49.0 & 14.8 & 32.6 \\
\hline Stenolobium stans & 45.0 & 152 & 6.85 & 47.6 & 20.4 & 36.2 \\
\hline Anadenanthera falcata & 54.6 & 94.2 & 11.1 & 22.5 & 22.4 & 19.0 \\
\hline Jacaranda mimosifolia & 63.2 & 116 & 14.8 & 50.3 & 26.3 & 32.3 \\
\hline Senna multijuga & 120.0 & 454.0 & 12.2 & 43.7 & 28.8 & 36.2 \\
\hline Mean for pionner species & 60.5 & 184.0 & 9.5 & 37.3 & 18.6 & 26.1 \\
\hline Cedrella fissilis & 37.4 & 246.0 & 4.8 & 58.6 & 12.0 & 39.5 \\
\hline Luehea grandiflora & 64.4 & 139.0 & 9.0 & 64.5 & 19.7 & 28.2 \\
\hline Senna macranthera & 102 & 436.0 & 8.9 & 46.3 & 26.9 & 38.9 \\
\hline Mean for secondary species & 67.9 & 274.0 & 7.5 & 56.5 & 19.5 & 35.5 \\
\hline Aspidosperma parvifolium & 31.9 & 57.1 & 9.8 & 16.8 & 8.1 & 3.4 \\
\hline Platycyamus regnellii & 76.7 & 177.0 & 7 & 18.7 & 10.7 & 7.4 \\
\hline Hymenaea courbaril & 33.8 & 63.6 & 10.5 & 15.2 & 10.6 & 10.5 \\
\hline Copaifera langsdorffii & 15.6 & 35.6 & 4.4 & 9.4 & 2.1 & 2.8 \\
\hline Mean for climax species & 39.5 & 83.3 & 7.8 & 15.0 & 7.9 & 6.0 \\
\hline Variation coefficient (\%) & & & & & & \\
\hline LSD soil liming (5\%) & & & & & & \\
\hline LSD species $(5 \%)$ & & & & & & \\
\hline
\end{tabular}


are higher in the pioneer and secondary species than in the climax species, in both soil treatments (Table 5). On the other hand, it was quite evident that the pioneer and secondary species were more efficient in $\mathrm{P}$ utilization when cultivated on limed soil. The climax species did not show significant differences in the PUE, but values were always greater under more acidic soil conditions (Table 5). The results of nutrient utilization efficiency are in agreement with those of Gonçalves et al. (1992), who also found that pioneer and secondary species have a higher CaUE, MgUE and PUE. According to Gonçalves et al. (1986), plants of Eucalyptus grandis were more efficient also in the $\mathrm{P}$ utilization when growing on a sandy acid soil with low initial levels of $\mathrm{Ca}$. In the present experiment, the soil used as substrate was a medium textured soil with low initial levels of $\mathrm{Ca}$ in the -LIM treatment (Table 1). The greater PUE of the climax species in the acid soil conditions might be related with the root system charactericstics, which is shorter and coarser than in the pioneer and secondary species (Gonçalves et al., 1992), leading to a lower capacity of P acquisition (Caradus, 1990).

It must be emphasized that, although both the pioneer and secondary group of plants in general presented higher CaUE, MgUE and PUE, some highly responsive species, such as T. micrantha, S. terebinthifolius and S. stans (pioneer species), and $C$. fissilis (secondary species), showed eventually smaller values for CaUE, MgUE and PUE when growing in the acid conditions (Table 5).

TABLE 5. The Ca, Mg and $P$ utilization efficiency (CaUE, MgUE and PUE), for woody species cultivated in the absence (-lim) and presence (+lim) of soil liming. Values are means of six replicates.

\begin{tabular}{|c|c|c|c|c|c|c|}
\hline \multirow[t]{2}{*}{ Species } & \multicolumn{2}{|c|}{ CaUE } & \multicolumn{2}{|c|}{$\mathrm{MgUE}$} & \multicolumn{2}{|c|}{ PUE } \\
\hline & $-\lim$ & $+\lim$ & $-\lim$ & $+\lim$ & $-\lim$ & $+\lim$ \\
\hline & \multicolumn{6}{|c|}{ - } \\
\hline Hovenia dulcis & 0.92 & 0.43 & 4.95 & 1.35 & 5.69 & 4.05 \\
\hline Trema micrantha & 0.04 & 0.09 & 0.28 & 0.60 & 0.29 & 1.07 \\
\hline Peltophorum dubium & 5.66 & 2.99 & 35.70 & 17.9 & 18.5 & 21.6 \\
\hline Schinus terebinthifolius & 1.08 & 1.51 & 9.06 & 6.20 & 3.84 & 9.40 \\
\hline Stenolobium stans & 4.54 & 3.39 & 29.90 & 10.8 & 9.99 & 14.3 \\
\hline Anadenanthera falcata & 1.82 & 0.66 & 8.96 & 2.77 & 4.41 & 3.27 \\
\hline Jacaranda mimosifolia & 2.47 & 2.04 & 10.50 & 4.82 & 5.87 & 7.66 \\
\hline Senna multijuga & 2.34 & 1.27 & 23.10 & 13.2 & 9.79 & 16.0 \\
\hline Mean for pioneer species & 2.35 & 1.54 & 15.30 & 7.20 & 7.30 & 9.66 \\
\hline Cedrella fissilis & 0.78 & 0.92 & 6.05 & 3.86 & 2.40 & 5.69 \\
\hline Luehea grandiflora & 0.88 & 1.40 & 6.45 & 2.93 & 2.86 & 6.77 \\
\hline Senna macranthera & 2.82 & 0.98 & 31.50 & 9.18 & 10.3 & 10.9 \\
\hline Mean for secondary species & 1.49 & 1.10 & 14.70 & 5.32 & 5.20 & 7.78 \\
\hline Aspidosperma parvifolium & 1.07 & 0.20 & 3.41 & 0.68 & 4.26 & 3.83 \\
\hline Platycyamus regnellii & 1.72 & 0.47 & 20.30 & 4.45 & 13.2 & 11.5 \\
\hline Hymenaea courbaril & 2.69 & 1.27 & 8.68 & 5.38 & 8.61 & 7.71 \\
\hline Copaifera langsdorffii & 0.71 & 0.31 & 2.49 & 1.18 & 5.35 & 4.60 \\
\hline Mean for climax species & 1.50 & 0.56 & 11.60 & 2.20 & 7.85 & 6.91 \\
\hline Variation coefficient (\%) & & & & & & \\
\hline LSD soil liming (5\%) & & & & & & \\
\hline LSD species $(5 \%)$ & & & & & & \\
\hline
\end{tabular}


The distinct capacity of the tree species in the CaUE, MgUE and PUE appears to contribute greatly to their performance in both unlimed and limed soil. This statement is supported by the significant correlation coefficient between the CaUE, MgUE and PUE and TDM in such conditions (Table 6). Since the $\mathrm{Ca}$ and $\mathrm{Mg}$ contents in the soil were very low when the experiment began, high correlations between CaUE and MgUE and the plant development in the -LIM treatment would probably occur. The probable reason for the close relationship between PUE and TDM in the unlimed soil, even that $\mathrm{P}$ was applied in the same quantity to both soil treatments (-LIM and +LIM), is that in acid soil conditions, like in the -LIM treatment (Table 1), fixing reactions must have reduced the $\mathrm{P}$ availability (Sanchez \&Salinas, 1981) during the experimental period, and then the PUE became too important. Although in the limed soil the plant $\mathrm{Ca}, \mathrm{Mg}$ and $\mathrm{P}$ content are higher than in the unlimed soil (Table 4), the significant correlation coefficient indicates that they also have high significance for the TDM, in that conditions.

Eventually, it can be inferred that the species which did not respond to lime application were tolerant to the existing soil Al level and/or tolerated the $\mathrm{H}^{+}$toxicity, because these ions appear, in some conditions, to be as toxic as $\mathrm{Al}$ (Brunet, 1994). Yet, these species probably have low $\mathrm{Ca}$ and $\mathrm{Mg}$ requirements. In fact, Duboc (1994) found that Copaifera langsdorffii and Hymenaea courbaril (climax species) grew well in soil with low levels of $\mathrm{Ca}$ and $\mathrm{Mg}$ because of their low requirements for these nutrients, whereas Peltophorum dubium, a $\mathrm{Ca}$ and $\mathrm{Mg}$ more exigent pioneer species, had a significant decrease in the TDM when growing in the same conditions. Similar results were also found for S. multijuga, Caesalpinea ferrea, C. fissilis and Piptadaenia gonoacantha (Renó, 1994). A high CaUE has been considered as a remarkable feature of the plants, which enable them to grow in low Ca levels (Horst et al., 1993). This characteristic has been suggested as a pre-requirement to the plant Al tolerance (Horst, 1987).

The ranking of the species in relation to their degree of tolerance to soil acidity (Fig. 1) showed species ranging from highly sensitive to highly tolerant ones. While Aspidosperma parvifolium and $P$. regnelli, and $H$. courbaril and $C$. langsdorffii (climax species) were classified respectively as highly tolerant and tolerant, growing very well in the acid soil (-LIM), only two pioneer species, H. dulcis and A. falcata, were capable of growing in such acid conditions. The pioneer species P. dubium, S. multijuga, J. mimosifolia, and the secondary species Senna macranthera, were ranked as moderately tolerant, demonstrating an intermediate development when planted in the unlimed soil. The other pioneer and secondary species only obtained good production when cultivated in the +LIM treatment, showing the highest responses to soil liming, thus being classified as highly sensitive and sensitive (Fig. 1). The results are consistent with those of Lambers \& Poorter (1992), who considered that species with slow growth rate, adapted to infertile environments, have a low nutrient utilization efficiency, demonstrating lower response to nutrient supply than those with fast growth rate.

From the present results, it can be concluded that species with faster growth rate, like pioneer and secondary ones, present the highest responses to soil liming, but that depend largely upon the specieps. Therefore, the information about plant

TABLE 6. The significant $(p<0.01)$ correlation coeficients obtained between the total dry matter production and the calcium, magnesium and phosphorus utilization efficiency of each ecological group in both absence (-lim) and presence (+lim) of soil liming.

\begin{tabular}{|c|c|c|c|c|c|c|}
\hline \multirow[t]{2}{*}{ Ecologic group } & \multicolumn{2}{|c|}{ CaUE } & \multicolumn{2}{|c|}{ MgUE } & \multicolumn{2}{|c|}{ PUE } \\
\hline & $-\lim$ & $+\lim$ & $-\lim$ & $+\lim$ & $-\lim$ & $+\lim$ \\
\hline Pioneer & 0.89 & 0.84 & 0.90 & 0.94 & 0.94 & 0.95 \\
\hline Secondary & 0.91 & 0.51 & 0.95 & 0.84 & 0.97 & 0.91 \\
\hline Climax & 0.78 & 0.71 & 0.86 & 0.96 & 0.77 & 0.83 \\
\hline
\end{tabular}




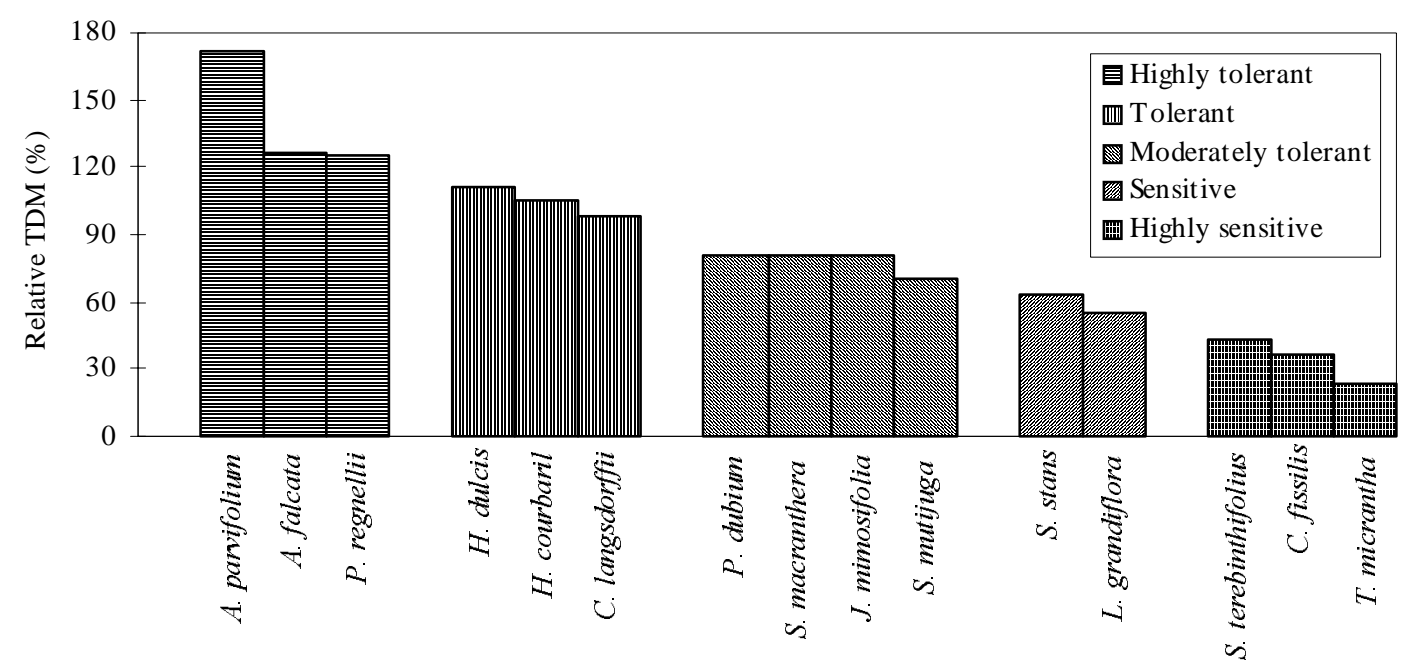

FIG. 1. Ranking of the species to soil acidity tolerance, according to the total dry matter (TDM) production in unlimed soil.

tolerance to infertility factors in acid soils will help in the allocation of each species or group of species according to its tolerance to soil acidity, optimizing the soil-plant interaction in the forestry activity.

\section{CONCLUSIONS}

1. Positive responses to soil liming, with higher biomass production and nutrient accumulation can be obtained only for the woody species classified as pioneer and secondary species.

2. The differential response of the woody species based on nutrient utilization efficiency is associated to their ecologic classification.

\section{AKNOWLEDGEMENTS}

To the CEMIG (Companhia Energética de Minas Gerais), as well to the CNPq (Conselho Nacional de Desenvolvimento Científico e Tecnológico), CAPES (Coordenadoria de Aperfeiçoamento de Pessoal de Nível Superior) and FAPEMIG (Fundação de Amparo à Pesquisa do Estado de Minas Gerais) for the financial support.

\section{REFERENCES}

ASHWATH, N.; DART, P.J.; EDWARDS, D.G.; KHANNA, P.K. Tolerance of Australian tropical and subtropical Acacias to acid soil. Plant and Soil, The Hague, v.171, n.1, p.83-87, 1995.

BLAMEY, F.P.C.; ASHER, C.J.; EDWARDS, D.G. Hidrogen and aluminium tolerance. Plant and Soil, The Hague, v.99, n.1, p.31-37, 1987.

BRUNET, J. Interacting effects of $\mathrm{pH}$, aluminium and base cations on growth and mineral composition of the woodland grasses Bromus benekenii and Hordelymus europaeus. Plant and Soil, The Hague, v.161, n.2, p.157-166, 1994.

BUDOWSKY, G. Distribuition of tropical american rain forest species in the light of successional processes. Turrialba, Turrialba, v.15, n.1, p.40-42, 1965.

CARADUS, J.R. Mechanism improving nutrient use by crop and herbage legumes. In: DUNCAN, R.R.; BALIGAR, V.C. (Eds.). Crops as enhancers of nutrient use. New York: Academic Press, 1990. p. 253-311.

COSTA FILHO, R.T. Crescimento de mudas de aroeira (Astronium urundeuva (Fr. All.) Engl.) em resposta 
à calagem, fósforo e potássio. Revista do Instituto Florestal, São Paulo, v.4, Edição Especial, Parte 2, p.537-543, 1992.

DELHAIZE, E.; RYAN, P.R. Aluminum toxity and aluminum tolerance in plants. Plant Physiology. Rockville, v.107, n.2, p.315-321, 1995.

DUBOC, E. Requerimentos nutricionais de espécies nativas: Hymenaea courbaril $\mathbf{L}$. var. stilbocarpa (Hayne) Lee et Lang. (jatobá); Copaifera langsdorffii Desf. (óleo copaíba) e Peltophorum dubium (Spreng.) Taub. (canafístula). Lavras: ESAL, 1994. 68p. Dissertação de Mestrado.

FOY, C.D. Plant adaptation to acid, aluminium-toxic soils Communications in Soil Science and Plant Analysis, New York, v.19, p.959-987, 1988.

GONÇALVES, J.L.M.; BARROS, N.F.; NEVES, J.C.L.; NOVAIS, R.F. Níveis críticos de fósforo no solo e na parte aérea de eucalipto na presença e ausência da calagem. Revista Árvore, Viçosa, v.10, n.1, p.91104, 1986

GONÇALVES, J.L.M.; KAGEYAMA, P.Y; FREIXÊDAS, V.M.; GONÇALVES, J.C.; GERES, W.L.A. Capacidade de absorção e eficiência nutricional de algumas espécies arbóreas tropicais Revista do Instituto Florestal, São Paulo, v.4, Edição Especial, Parte 2, p.463-469, 1992.

HORST, N.J. Aluminum tolerance and calcium efficiency of cowpea genotypes. Journal of Plant Nutrition, New York, v.10, p.1121-1129, 1987.

HORST, N.J.; CURRLE, C.; WISSEMEIER, A.H Differences in calcium efficiency between cowpea (Vigna unguiculata (L.) Walp.) cultivars. In: RANDALL, P.J.; DELHAIZE, E.; RICHARDS, R.A.; MUNNS, R. (Eds.). Genetic aspects of plant mineral nutrition. The Netherlands: Kluwer Academic, 1993. p. 59-68.

HUANG, J.; BACHELARD, E.P. Effects of aluminium on growth and cation uptake in seedlings of Eucalyptus mannifera and Pinus radiata. Plant and Soil, The Hague, v.149, n.1, p.121-127, 1993.

LAMBERS, H.; POORTER, H. Inherent variations in growth rate between higher plants: A search for physiological causes and ecological consequences. Advances in Ecological Research, London, v.23, p.188-261, 1992.
LOPES, A.S. Solos sob cerrado: características, propriedades e manejo. Piracicaba: Instituto da Potassa e Fosfato/Instituto Internacional da Potassa, 1983. $162 \mathrm{p}$

NIELSEN, G.H.; NIELSEN, D.; ATKINSON, D. Top and root growth and nutrient absorption of Prunus avium $\mathrm{L}$. at two soil $\mathrm{pH}$ and $\mathrm{P}$ levels. Plant and Soil, The Hague, v.121, n.1, p.137-144, 1990.

RENÓ, N.B. Requerimentos nutricionais e resposta ao fósforo e fungo micorrízico de espécies arbóreas nativas do sudeste brasileiro. Lavras ESAL, 1994. 62p. Dissertação de Mestrado.

RITCHEY, K.D.; SILVA, J.E.; COSTA, V.F. Calcium deficiency in clayey B horizons of savannah oxisols. Soil Science, Baltimore, v.133, n.4, p.378-382, 1982.

SANCHEZ, P.A.; SALINAS, J.G. Low input technology for managing Oxisols and Ultisols in tropical America. Advances in Agronomy, New York, v.34, p.280406, 1981

SANZONOWICZ, C.; SMYTH, T.J. Effect of hydrogen on soybean root growth in a subsurface solution. Pesquisa Agropecuária Brasileira, Brasília, v.30, n.2, p.255-261, 1995.

SIDDIQI, M.Y.; GLASS, A.D.M. Utilization index: a modified approach to the estimation and comparison of nutrient utilization efficiency in plants. Journal of Plant Nutrition, New York, v.4, p.289-302, 1981

SIQUEIRA, J.O.; CURI, N.; VALE, F.R.; FERREIRA, M.M.; MOREIRA, F.M.S. Aspectos de solos, nutrição vegetal e microbiologia na implantação de matas ciliares. Belo Horizonte: CEMIG, 1995. $28 \mathrm{p}$.

SMYTH, T.J.; CRAVO, M.S. Aluminum and calcium constraints to continuous crop production in a Brazilian Amazon Oxisol. Agronomy Journal, Madison, v.84, n. 5 , p.843-850, 1992

TAN, K.; KELTJENS, W.G. Analysis of acid-soil stress in sorghum genotypes with emphasis on aluminium and magnesium interactions. Plant and Soil, The Hague, v.171, n.1, p.147-150, 1995.

VALE, F.R. do; FURTINI NETO, A.E.; RENÓ, N.B.; FERNANDES, L.A.; RESENDE, A. V. Crescimento radicular de espécies florestais em solo ácido. Pesquisa Agropecuária Brasileira, Brasília, v.31, n.9, p.609-616, 1996. 